\title{
CLINICAL CHARACTERISTICS AND SURGICAL OUTCOME OF PATIENTS WITH TEMPORALLOBE TUMORS AND EPILEPSY
}

\author{
CARMEN LISA J ORGE*, SUELY K. NAGAHASHI-MARIE*, CHRISTIANE C. PEDREIRA*, \\ SÉRGIO ROSEMBERG**, ROSA M.F. VALÉRIO*, KETTE D.R. VALENTE*, ELZA M.T. YACUBIAN*
}

\begin{abstract}
This is a retrospective study of 21 surgically treated patients with temporal lobe tumors and epilepsy. Evaluation included clinical data, EEG findings, structural scans, pathological diagnosis and postsurgical follow-up. There were 9 cases of ganglioglioma, 5 pilocytic astrocytoma, 3 ganglioneuroma, 2 dysembryoplastic neuroepithelial tumor, 1 pleomorphic xantoastrocytoma, and 1 meningioangiomatosis. Mean follow-up time was 22 months and outcome was evaluated according to Engel's classification; $76.2 \%$ were classified in class I and $23.8 \%$ in II and III. All patients classes II and III had been submitted to mesial and neocortical resections. There were no differences related to clinical characteristics, pathological diagnosis or duration of follow-up in patients seizure-free or not. All patients had abnormal MRI and ten of these had normal CT; the MRI characteristics were compared to pathological diagnosis and specific histological characteristics of the tumors were not discernible by MRI. We concluded that MRI was essential for the diagnosis and precise location of TL tumors. Ganglioglioma was the most frequent tumor and lesionectomy associated to mesial resection doesn't guarantee a better prognosis.
\end{abstract}

KEY WORDS: epilepsy, temporal tumor, clinical aspects, surgical outcome, MRI.

\section{Características clínicas, de neuroimagem estrutural e prognóstico cirúrgico de pacientes com tumor do lobo temporal e epilepsia}

RESUMO - Este é um estudo retrospectivo de 21 pacientes com epilepsia e tumores do lobo temporal tratados cirurgicamente. A avaliação incluiu dados clínicos, eletrencefalográficos, de neuroimagem, anatomia patológica e seguimento pós-operatório. Eram 9 casos de ganglioglioma, 5 de astrocitoma pilocítico, 3 de ganglioneuroma, 2 de tumor neuroectodérmico disembrioplástico, 1 de xantoastrocitoma pleomórfico e 1 de meningoangiomatose. A média de tempo de seguimento pós-operatório foi 22 meses e o prognóstico foi avaliado de acordo com a classificação de Engel; 76,2\% encontravam-se na classe I e o restante nas classes II e III. Todos os pacientes que se encontravam nas classes II e III haviam sido submetidos a ressecção do tumor e de estruturas mesiais temporais. Não encontramos diferenças entre os grupos quanto as características clínicas, histológicas e tempo de seguimento. Dez pacientes apresentavam TC normal; os achados na RM foram comparados ao diagnóstico patológico, mas não encontramos características específicas relacionadas ao tipo de tumor. O estudo por RM foi essencial para o diagnóstico e localização precisa da lesão. Ganglioglioma foi o tumor mais freqüente e lesionectomia associada a ressecção mesial não proporcionou melhor prognóstico. magnética.

PALAVRAS-CHAVE: epilepsia, tumor do lobo temporal, clínica, prognóstico cirúrgico e ressonância

New neuroimaging techniques, especially MRI, have allowed more frequent detection of structural abnormalities, such as discrete neuronal migration disorders, gliosis and slow growing tumors in patients with medically refractory epilepsy ${ }^{1}$. Small growing tumors are found in about 10-

Department of Neurology* and Pathology**, University of São Paulo Medical School (FMUSP), São Paulo, Brazil. Aceite: 22-julho-2000.

Dra. Carmen Lisa Jorge - Epilepsy Group, Divisão de Neurologia, Hospital das Clínicas FMUSP - Av. Dr. Enéas de Carvalho Aguiar - 05403-000 São Paulo SP - Brasil. Fax: 1130697149. 
$20 \%$ of patients who undergo surgical treatment of temporal lobe medically refractory epilepsy ${ }^{2-4}$. Due of the benign nature of these lesions, recurrent, often refractory epilepsy, epileptic seizures are the usual presentation of these lesions, mass effect signs or bleeding are characteristically absent in this setting.

We present the clinical, electroencephalographic, neuroimaging and pathological and surgical follow-up in a series of patients with refractory epilepsy and temporal tumor, who were submitted to surgical resection for treatment of refractory seizures.

\section{METHOD}

We present the retrospective clinical, EEG, neuroimaging, pathological and surgical follow-up data of 21 consecutive patients with refractory epilepsy secondary to temporal lobe tumors (TLT), who underwent surgical treatment at the Hospital das Clínicas da Faculdade de Medicina da Universidade de São Paulo.

We analysed the impact on outcome (seizure free patients - Engel's class I vs. non-seizure free patients) of the following factors: localization of TLT (mesial, neocortical or mesial and neocortical) pathological diagnosis, type and extension of the resection, clinical features (age of onset, duration of epilepsy and seizure type and frequency) and interictal and ictal EEG findings.

Pathological diagnosis was also analyzed in relation to neuroimaging (MRI) features: localization of the lesion and presence or absence of infiltration, calcification, edema, cysts and contrast enhancement.

The student's t test (two-tailed) was used to evaluate differences between age, age at seizure onset, duration of follow-up, seizure frequency, duration of follow-up. Fisher's exact test (two-tailed) were used to assess the association of the two groups in relation to the presence of generalized tonic-clonic seizures (GTCS) and simple partial seizure (SPS) and characteristics of EEG. The others aspects didn't allow statistical analysis because of the small number of patients.

\section{RESULTS}

In this series there were 12 males and 9 females. There were 9 cases of ganglioglioma (42.8\%), 5 pilocytic astrocytoma, 3 ganglioneuroma, 2 dysembryoplastic neuroepithelial tumor (DNET), 1 pleomorphic xanthoastrocytoma, and 1 case of meningioangiomatosis associated to mesial temporal sclerosis.

The mean follow-up time was 22 months ( 3 to $63 \mathrm{mo}$ ) and the outcome was evaluated according to Engel's classification; $76.2 \%$ of the patients were classified in class I, $14.3 \%$ in II and $9.5 \%$ in III. All patients were submitted to total tumor resection except for two who needed a second procedure due to partial resection at the time of the first surgery. No tumoral recurrence has been detected up to this moment. The surgical procedure consisted of lesionectomy in all patients. Seven out of the 10 patients with neocortical lesions also had a partial resection of the mesial temporal structures; all these patients had had a suggestion of memory impairment in the neuropsychological evaluation; two also presented signs of mesial temporal sclerosis on MRI and in four the lesions were located in the inferior basal temporal lobe, nearby the mesial structures. Three patients with small circumscribed lesions involving the neocortex did not have any mesial resection. Examples of the resections (involving the mesial temporal structures or not) can be seen in Figures 1 and 2.

All patients classes II and III had been submitted to mesial and neocortical resections and there were no differences related to location, pathological diagnosis or duration of the follow-up in patients seizure-free or not (Table 1). There were differences between patients classes I (seizure free) and II and III (no-seizure free) in relation to duration of epilepsy, age at the evaluation and age of epilepsy onset. The mean duration of epilepsy was $7.56 \mathrm{y}$, the age at the time of the surgery, 14.2 $\mathrm{y}$ and age of epilepsy onset $6.68 \mathrm{y}$ in patients seizure free. In the ones who continue to present seizures, the mean duration of epilepsy was $15.8 \mathrm{y}$, the age at the time of the surgery, $28.4 \mathrm{y}$ and age at the time of epilepsy onset 12.6y, but no significant association with prognosis was found (Table 2).

All patients were considered refractory to medical treatment and presented complex partial seizures (CPS). In the seizure free group the seizure frequency ranged from 2 to 45 per month (mean: 10.25) and in the non seizure free group ranged from 6 to 180 (mean: 52.8). Nine $(56.25 \%)$ 


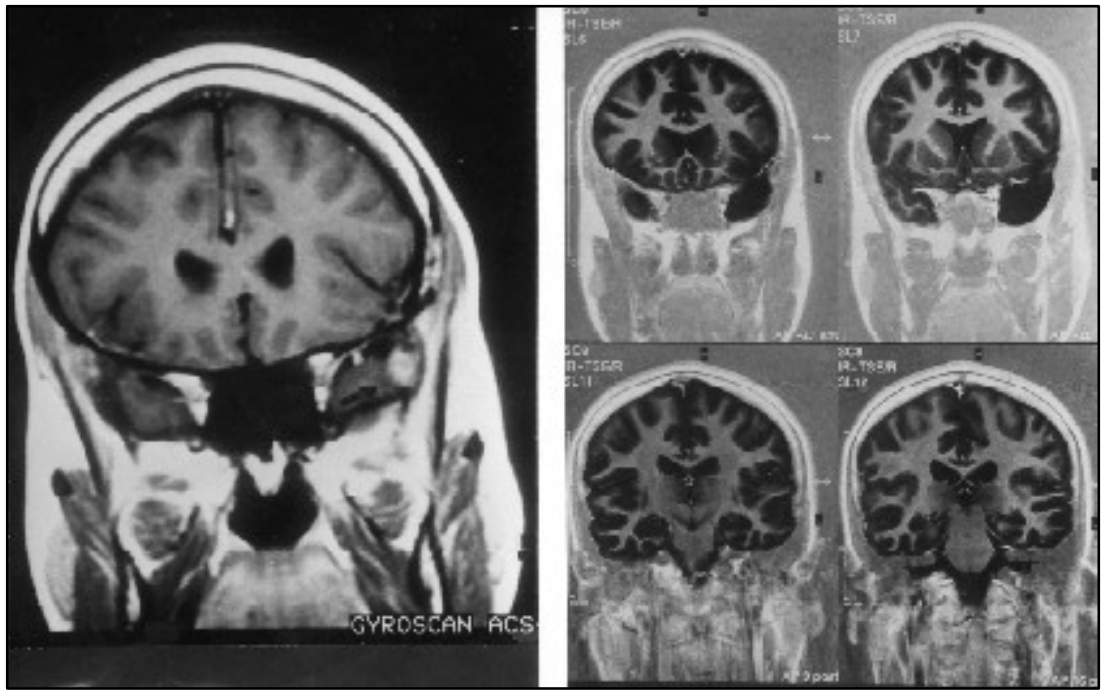

Fig 1. A polar left temporal lobe lesion. Pre (A) and postoperative $(B)$ aspects. The mesial temporal structures are preserved (pleomorphic xanthoastrocytoma).
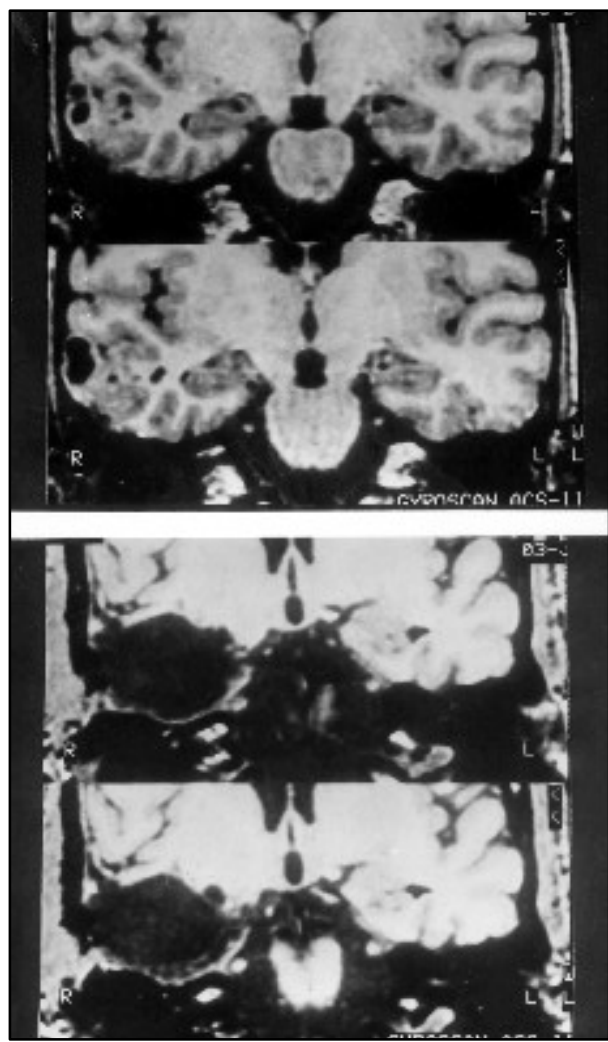

Fig 2. A lesion (ganglioneuroma) located in the right ment (9.5\%), but specific histological characteristemporal neocortex. Pre $(A)$ and postoperative $(B)$ tics of the tumors were not discernible by MRI aspects. The mesial temporal structures were removed. (Table 4 and Figure 3). 
Table 1. Prognostic factors: localization, histological diagnoses and resection.

\begin{tabular}{|c|c|c|c|}
\hline Prognostic factors & $\begin{array}{l}\text { Patients seizure-free } \\
\text { (Engel's Class I) } \\
\text { n=16 }\end{array}$ & $\begin{array}{l}\text { Patients no seizure-free } \\
\text { (Engel's Classes II and III) } \\
n=5\end{array}$ & $\mathrm{p}$ Value \\
\hline $\begin{array}{l}\text { Localization: } \\
\text { mesial } \\
\text { neocortical } \\
\text { neocortical and mesial }\end{array}$ & $\begin{array}{l}7 \\
8 \\
1\end{array}$ & $\begin{array}{l}2 \\
2 \\
1\end{array}$ & $*$ \\
\hline $\begin{array}{l}\text { Etiology: } \\
\text { ganglioglioma } \\
\text { ganglioneuroma } \\
\text { pilocytic astrocytoma } \\
\text { others }\end{array}$ & $\begin{array}{l}7 \\
3 \\
3 \\
4\end{array}$ & $\begin{array}{l}2 \\
0 \\
2 \\
1\end{array}$ & $*$ \\
\hline $\begin{array}{l}\text { Resection: } \\
\text { some mesial resection } \\
\text { without mesial resection }\end{array}$ & $\begin{array}{l}13(81.25 \%) \\
03(18.25 \%)\end{array}$ & $\begin{array}{c}05(100 \%) \\
0\end{array}$ & $0,54^{\mathrm{b}}$ \\
\hline $\begin{array}{l}\text { Postoperative follow-up } \\
\text { (months) }\end{array}$ & $\begin{array}{l}\text { mean: } 20.4 \\
(3-63)\end{array}$ & $\begin{array}{l}\text { mean: } 27.6 \\
\quad(7-52)\end{array}$ & $0.46^{\mathrm{b}}$ \\
\hline
\end{tabular}

* The small number of patients didn't allow statistical analysis. b: p value based on t- test (2-tail).

Table 2. Prognosticfactors: clinical aspects

\begin{tabular}{lccc}
\hline & $\begin{array}{c}\text { Patients seizure-free } \\
\text { (Engel's Class I) } \\
\mathrm{n}=16\end{array}$ & $\begin{array}{c}\text { Patients no seizure-free } \\
\text { (Engel's Classes II and III) } \\
\mathrm{n}=5\end{array}$ & $\mathrm{p}$ Value \\
\hline Age (years) & $14.25(4-27)$ & $28.4(7-51)$ & $0.27^{\mathrm{b}}$ \\
Age of epilepsy onset & $6.68(05-19)$ & $12.6(1.5-43)$ & $0.49^{\mathrm{b}}$ \\
Duration of epilepsy & $7.56(1-19)$ & $15.8(3.5-30)$ & $0.16^{\mathrm{b}}$ \\
CPS & $100 \%$ & $100 \%$ & - \\
CPS (month frequency) & $10.31(1-45)$ & $52.8(6-180)$ & $0.26^{\mathrm{b}}$ \\
SPS & $56.25 \%(9)$ & $20 \%(1)$ & $0.31^{\mathrm{a}}$ \\
GTCS & $37.5 \%(6)$ & $40 \%(2)$ & $1.00^{\mathrm{a}}$ \\
GTCS (annual frequency) & mean $: 3.06(1-12)$ & 12 & $0.28^{\mathrm{b}}$ \\
Status epilepticus & $18.75 \%(3)$ & $20 \%(1)$ & $1.00^{\mathrm{a}}$ \\
\hline
\end{tabular}

CPS: complex partial seizure, SPS: simple partial seizure, GTCS: generalized tonic clonic seizure. a, p value based on Fisher's exact test (2-tail) b, p value based on t- test (2-tail).

Table 3. Electroencephalogram data.

\begin{tabular}{lccc}
\hline Electroencephalogram & Patients seizure-free & Patients no seizure-free & $\mathrm{p}$ Value \\
\hline Interical (localizatory) & $9 / 16$ & $0 / 5$ & $0.11^{\mathrm{a}}$ \\
Ictal (lateralizatory) & $(56.25 \%)$ & $3 / 3$ & - \\
\hline
\end{tabular}

a, p value based on Fisher's exact test (2-tail).

SPECT images were obtained during interictal period in 10 patients and were abnormal in 9 , showing hypoperfusion in the area of the tumor in 8 and hyperperfusion in 1. Hyperperfusion was demonstrated in all 6 patients who had ictal SPECT studies. 


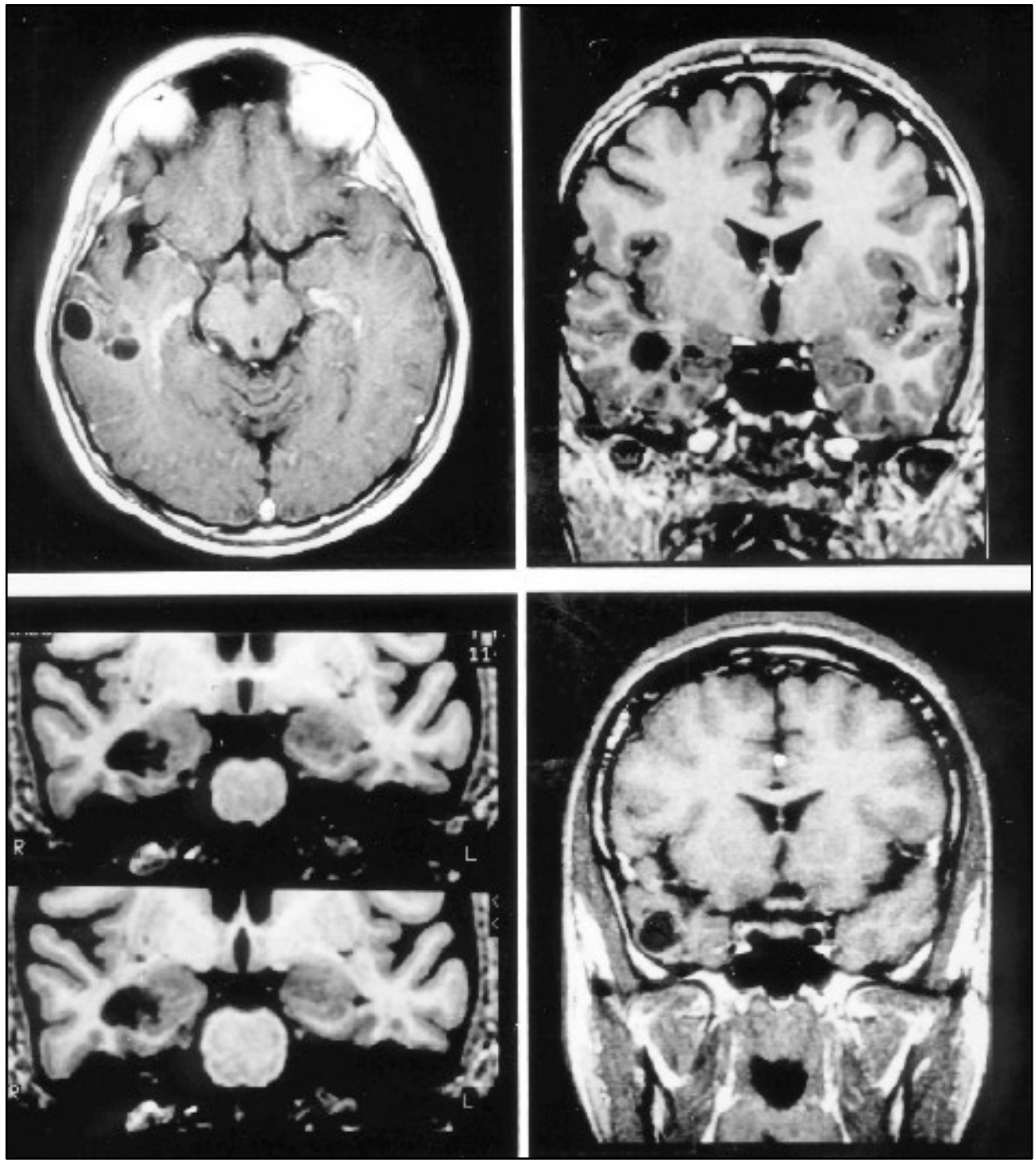

Figure 3. MRI pre operative with similar characteristics in four patients with different pathological diagnosis: (A) ganglioneuroma, (B) pilocytic astrocytoma, (C) dysembrioplastic neuroepithelial tumor and (D) ganglioma.

\section{DSSCUSSION}

In this series there were important variations in the duration of epilepsy (up to $43 \mathrm{y}$ ) and age at the time of surgery. As reported by others ${ }^{5-7}$, the TLT related to epilepsy have a benign course explaining the long duration of epilepsy.

The most common tumor, as also emphasized by others ${ }^{2,4,5}$, was ganglioglioma. This tumor accounts for $0.4-9 \%$ of primary brain tumors diagnosed at different institutions, and has been described in all parts of central nervous system, but more commonly comes to clinical attention when present in the cerebral hemispheres, particularly in the temporal lobe ${ }^{7}$.

The histopathological classification of the expansive lesions found in temporal lobe may be difficult, due to the fact that they can resemble both tumors and dysembryogenic lesions ${ }^{9-11}$. In two 
Table 4. MRI characteristics and pathological diagnoses.

\begin{tabular}{|c|c|c|c|c|c|c|}
\hline \multirow{2}{*}{$\begin{array}{l}\text { Pathological } \\
\text { diagnoses (n) }\end{array}$} & \multirow[b]{2}{*}{ Localization } & \multirow[b]{2}{*}{ Infiltration } & \multicolumn{2}{|c|}{ MRI Characteristics } & \multirow{2}{*}{$\begin{array}{l}\text { Contrast } \\
\text { enhan- } \\
\text { cement }\end{array}$} & \multirow[b]{2}{*}{ Cyst } \\
\hline & & & Calcification & Edema & & \\
\hline Ganglioglioma(9) & $\begin{array}{c}\mathrm{M}=6 \\
\mathrm{~N}=2 \\
\mathrm{M}+\mathrm{N}=1\end{array}$ & 3 & 4 & 4 & 5 & 3 \\
\hline Pilocytic astrocytoma (5) & $\begin{array}{c}\mathrm{N}=4 \\
\mathrm{M}+\mathrm{N}=1\end{array}$ & 4 & 2 & - & 4 & 1 \\
\hline Ganglioneuroma(3) & $\begin{array}{l}\mathrm{M}=2 \\
\mathrm{~N}=1\end{array}$ & 3 & - & - & 1 & 1 \\
\hline Dysembryoplastic neuroepithelial (2) & $M=2$ & 2 & - & - & - & - \\
\hline Pleomorphic xanthoastrocytoma (1) & $\mathrm{N}=1$ & - & 1 & - & 1 & - \\
\hline Meningioangiomatosis (1) & $\mathrm{N}=1$ & 1 & - & 1 & 1 & - \\
\hline
\end{tabular}

$\mathrm{M}$, mesial; N, neocortical

of our patients with DNET there were evidences of tumoral and malformative characteristics. In this type of tumor, first described by Daumas-Duport et al ${ }^{10}$, epilepsy may be the only clinical finding. It usually presents a good prognosis. One of these patients had a poor outcome, maybe because of the fact that it was associated to neurofibromatosis. The other lesions found in this series were also slow growing tumors of benign nature.

Brain MRI was essential for the diagnosis of TLT since CT studies were normal in about half of the patients. Although the sensitivity of MRI is very high, this method didn't show any specific characteristics for each of the histological types. There was a great variability in MRI characteristics in the ganglioglioma group although our number of patients is small to allow for conclusive statements. The findings were variable, such as, cystic and solid areas, signal intensity abnormalities, calcifications and contrast enhancement ${ }^{1,12}$.

The ideal surgical procedure in patients with TLT has been discussed in the literature. The temporal lobe contains structures implied in seizure generation or amplification of the epileptic activity such as the hyppocampal formation ${ }^{13}$. There are also controversies if the mesial temporal structures should or not be resected. Different surgical approaches have been used varying from simple lesionectomy to total lobectomy including the hyppocampus and amygdala. In some series as ours the inclusion of the mesial temporal structures didn't promote a better prognosis ${ }^{7,14,15}$ while in others extensive resections implied in control of the seizures ${ }^{3,16,17}$. Studies have identified incomplete tumor resections or tumor recurrences as a important cause of a poor postoperative seizure control ${ }^{8,18-20}$. In this series two patients with partial resection of the tumor still presented seizures; after total remotion of the lesion they became seizure free.

In accordance with other authors ${ }^{6,7,21}, 76.2 \%$ of the patients have been seizure-free. These surgical results are similar to those that studied mesial temporal sclerosis, that has a well-known good surgical outcome ${ }^{22-25}$.

The mean age at the time of evaluation, the age at onset and duration of epilepsy were lower in seizure free group although this data was not statistically significant. This may be attributed to the small number of patients or variability in histopathological diagnoses ${ }^{8,20,26}$. Morris et al. ${ }^{8}$, observed in thirty-eight gangliogliomas a worse prognosis in terms of seizures in older patients with long duration of epilepsy, although Cascino et al. ${ }^{16}$ and Jennum et al. ${ }^{27}$ couldn't demonstrate this relation in patients with benign tumors. These studies were also small or contained a heterogeneous group of patients with several types of tumors or lesions. Precocious surgery should be considered in the evaluation of these patients due to cognitive and psychosocial consequences of chronic epilepsy ${ }^{28,29}$ and, perhaps, better seizure control ${ }^{7}$. 


\section{Conclusions}

1. Brain MRI was essential for the diagnosis but didn't show specific characteristics for each of the histological types of tumors.

2. The most common TLT was ganglioglioma.

3. The good surgical results were similar to other series that include mesial temporal sclerosis.

4. Lesionectomy associated with partial mesial resection did not guarantee a better prognosis.

Acknowledgements - Os autores agradecem a: CAPES, Coordenação de Aperfeiçoamento de Pessoal de Nível Superior; Setor de Imagem do Instituto do Coração da Faculdade de Medicina da Universidade de São Paulo; Dr. Luiz Henrique Martins Castro.

\section{REFEREICES}

1. Kuzniecky RI, Jackson GD. Temporal lobe epilepsy. In Kuzniecky RI, Jackson GD (eds). Magnetic resonance in epilepsy. New York: Raven Press, 1994: 151-182.

2. Babb TL, Brown JW. Pathological findings in epilepsy. In Engel J Jr (ed). Surgical treatment of the epilepsies. New York: Raven Press, 1987: 511-540.

3. Boon PA, Williamson PD, Fried I. Intracranial intraaxial, space-occupying lesions in patients with intractable partial seizures: an anatomoclinical, neuropsychological, and surgical correlation. Epilepsia 1991;32:467-476.

4. Spencer DD, Spencer SS, Mattson RH. Intracerebral masses in patients with intractable partial epilepsy. Neurology 1984;34:432-436.

5. Vinters HV, Armstrong DL, Babb TL, et al. The neuropathology of human symptomatic epilepsy. In Engel JJr (ed). Surgical treatment of the epilepsies. New York: Raven Press, 1993: 593-608.

6. Çatalpe O, Comair Y. Surgical outcome in patients with epilepsy with temporal lobe tumor (Abstr). Epilepsia 1997;38(Suppl 8):82.

7. Morris HH, Matkovic Z, Estes ML, et al. Ganglioglioma and intractable epilepsy: clinical and neurophysiologic features and predictors of outcome after surgery. Epilepsia 1998;39:307-313.

8. Morris HH, Estes ML, Gilmore R, Van Ness PC, Barnett GH, Turnbull J. Chronic intractable epilepsy as the only symptom of primary brain tumor. Epilepsia 1993;34:1038-1043.

9. Armstrong DD. The neuropathology of temporal lobe epilepsy. J Neuropathol Exp Neurol 1993;52:433-443.

10. Daumas-Duport C, Sheithauer BW, Chodkiewicz JP, Laws ER, Vedrenne C. Dysembryoplastic neuroepithelial tumor: a surgically curable tumor of young patients with intractable partial epilepsy. Report of thirty-nine cases. Neurosurgery 1988;23:545-556.

11. Haddad SF, Moore SA, Menezes AH, Van Gilder JC. Ganglioglioma: 13 years of experience. Neurosurgery 1992;31:171-178.

12. Meiners LC. Epileptogenic lesions requiring additional MRI studies. Epilepsia 1997;38 (Suppl 10):19-23.

13. Sloviter RS. The functional organization of the hippocampal dentate gyrus and its relevance to the pathogenesis of temporal lobe epilepsy. Ann Neurol 1994;34:640-654.

14. Goldring S, Rich K, Picker S. Experience with gliomas in patients presenting with a chronic seizure disorder. In Little JR (ed). Clinical neurosurgery, vol 33. Baltimore: Williams \& Wilkins, 1986:15-42.

15. Fried I, Kim JH, Spencer DD. Limbic and neocortical gliomas associated with intractable seizures: a distinct clinicopathological group. Neurosurgery 1994;34:815-823.

16. Cascino GD, Kelly PJ, Sharbrough FW, Hulihan JF, Hirschorn KA, Trenerry MR. Long-term follow-up of stereotactic lesionectomy in partial epilepsy: predictive factors and electroencephalographic results. Epilepsia 1992;33:639-644.

17. Yeh H, Kashiwagi S, Tew JM, Berger TS. Surgical management of epilepsy associated with cerebral arteriovenous malformations. J Neurosurg 1990;72:216-223.

18. Awad IA, Rosenfeld J, Ahl H, Hahn JF, Lüders H. Intractable epilepsy and structural lesions of the brain: mapping, resection strategies and seizure outcome. Epilepsia 1991;32:179-186.

19. Britton JW, Cascino GD, Sharbrough FW, Kelly PJ. Low-grade glial neoplasms and intractable partial epilepsy: efficacy of surgical treatment. Epilepsia 1994;35:1130-1135.

20. Packer RJ, Sutton LN, Patel KM. Seizure control following tumor surgery for childhood cortical low grade gliomas. J Neurosurg 1993;80:998-1003.

21. Cascino GD, Boon PAJM, Fish DR. Surgically remediable lesional syndromes. In Engel J Jr (ed). Surgical treatment of the epilepsies. New York: Raven Press, 1993;77-86.

22. Jorge CL, Grossmann RM, Yacubian EMT, Valério RMF. Epilepsia com esclerose mesial temporal: aspectos clinicos e histopatológicos. BJECN 1996;2:215-227.

23. Wieser HG, Engel JJr, Williamson PD, Babb TL, Gloor P. Surgically remediable temporal lobe syndromes. In: Engel JJr (ed). Surgical treatment of epilepsies. New York: Raven Press, 1993;49-63.

24. Rasmussen T, Feindel W. Temporal lobectomy: review of 100 cases with major hippocampectomy. Can J Neurol Sci 1991;18:601-602.

25. Feindel W, Rasmussen T. Temporal lobectomy with amygdalectomy and minimal hippocampal resection: review of 100 cases. Can J Neurol Sci 1991; 18:603-605.

26. Berger MS, Ghatan S, Haglund MM, Bobbins J, Ojemann GA. Low-grade gliomas associated with intractable epilepsy seizure outcome utilizing electrocorticography during tumor resection. J Neurosurg 1993;79:62-69.

27. Jennum P, Dhuna A, Davies K, Fiol M, Maxwell R. Outcome of resective surgery for intractable partial epilepsy guided by subdural electrode arrays. Acta Neurol Scand 1993;87:434-437.

28. Williams BA, Abbott KJ, Manson JI. Cerebral tumors in children presenting with epilepsy. J Child Neurol 1992;7:291-294.

29. Engel JJr. Etiology as a risk factor for medically refractory epilepsy: a case for early surgical intervention. Neurology 1998;51:1243-1244. 